\title{
Research on Operation Model of Mortgage Backed Securitization in Foreign
}

\author{
QU WANCHENG \\ College of Management and Economics, Tianjin University, Tianjin \\ SUN JINSHUAI \\ Post-doctoral Scientific Research Workstation, Northern International Trust CO., LTD, Tianjin
}

\begin{abstract}
Mortgage backed securitization is one of the most important international financial innovations since the 1970s. This paper firstly summarizes the existing four financing housing loans models in the international. Then analyzes the operation mode of mortgage backed securitization in the different countries and regions, and the variety modes are classified and compared. Finally we draw the conclusions of this study. KEYWORD: Mortgage Backed Securitization; Financing Model; Operation Model
\end{abstract}

\section{INTRODUCTION}

Mortgage backed securitization is one of the most important international financial innovations since the 1970s. Many western countries have it as the main way to development the secondary market of housing finance. Because the background and development status of the mortgage market are different, the operational process of securitization model in countries and regions differ from each other. To study the implementation status of mortgage securitization in developed countries and regions, summary the background and advantages and disadvantages of the different mortgage securitization model, they have an important reference to further carry out large scale mortgage securitization business in our country.

\section{THE SITUATION OF HOUSING MORTGAGE MARKET IN ABROAD}

The organizational structure of mortgage market and the characteristics of mortgage product may affect the mode selection of the mortgage securitization. We choose America for example, the residential mortgage market in America basically represents the development direction of mortgage market under market economy conditions, many developing countries emulate the way of government regulation, market model, operation mechanism and financial tools. Now, the housing finance market in America has become the largest in the world, it has three characteristics[1]. First, government and private sector participate in mortgage insurance guarantee mechanism. Second, government promotes that the residential mortgage market has become relatively independent of the complete market system. Third, the real estate securitization has become an important trend in the development of real estate finance in modern Western.

\subsection{The loan originator of the first mortgage market in America}

There are three types of first mortgage market and participants in America. Supply-side in financing activities, it is namely lender. Demand-side in financing activities, it is namely borrower. Intermediaries in financing activities, it is mainly the guarantor. The borrower is basically the residents and families need to buy a house, we mainly introduce the lenders and guarantors.

\subsection{The lender of the mortgage market in America}

There are many kinds of financial institutions in America, there are several major financial institutions to provide mortgage services at present[2]. It includes Saving and Loan Association, Commercial Bank, Mutual Saving Bank, Credit Unions, Life Insurance Company, Mortgage Banker and Personal Loans.

\subsection{The guarantor of the mortgage market in America}

It includes FHA, Veterans Administration and Private Mortgage Insurers. 


\subsection{The loan originator of the second mortgage market in America}

The guarantee system about primary mortgage market can effectively solve the problem of mortgage default risk, but there are two problems to be solved, they are liquidity risk and interest rate risk, the interest rate risk also includes the prepayment risk which can cause refinance. So the America establishes several government and quasigovernment institutions through a series of legislation, they play a role of secondary market maker for mortgage market. The participants in the secondary market include the supply side, market makers, intermediaries and investors.

\subsection{The market makers of the secondary mortgage market in America[3]}

It includes Federal National Mortgage Association, Government National Mortgage Association, Federal Home Loan Mortgage Corporation and Privately Guaranteed Security.

\subsection{The investors of the secondary mortgage market in America [4]}

Similarly with the US stock market, the investors of the secondary mortgage market in America primarily are institutional investors, it includes pension funds, life insurance companies and other securities investment funds. The diversification of mortgage founding institutions has resulted in competition among lenders, it enhances the efficiency of the market and effectively reduces the financing costs of the borrowers.

\section{THE ANALYSIS OF FINANCING MODE ABOUT INTERNATIONAL HOUSING FINANCE}

According to the different sources of financing housing loans, the financing model internationally can be summarized into four basic types, includes the national housing bank mode, forced housing savings mode, contractual housing savings mode and the commercial capital market mode[5]. The housing finance system may be one of the several types, it also two or three of the several types.

\subsection{Public Housing Bank}

The Japan Residential Finance Corporation longterm accounts for 25\%-35\% Japan's housing loans markets. In South Korean, before the financial market open in mid-1990s, the state-owned National Housing Fund is the main part of housing finance, it accounts for half of the total housing loans.

\subsection{Mandatory Housing Savings}

The government uses public rights to force some residents which have wage income to do regular housing saving, the employers have modest proportion, it has an imputation large-scale housing loan funds. The participants can get preferential loans lower than the market interest rate, the line of credit linked with pre-existing deposits, the deposits are tax-free. The most prominent representative in this regard is the housing fund in Singapore, the housing fund in China is very similar. In addition, Brazil and other countries have similar institutional arrangement, it is the unemployment and guarantee fund.

\subsection{Contract Housing Savings Financing}

We obtain housing loan funds by imputation residents voluntary savings contract by contract. The loan amount is generally combined with pre-existing savings, but also exists the separation. Low deposit low loans, it has an internal closed operation. There is an exact match capital flows. It also generally has a variety of government incentives.

\subsection{Business Capital Market Financing}

The mortgage payment institutions (commercial banks) obtain housing loans funding by sequestration residents demand and time deposits, savings deposits or issuing mortgage-backed securities in the secondary market. This is the most common mortgage financing model, it also dominates even in the countries where compulsory housing savings and contract housing savings. The national housing bank in every country often plays only a complementary and supplementary role.

\section{THE OPERATION MODE OF MORTGAGE SECURITIZATION AMONG DIFFERENT COUNTRIES AND REGIONS}

\subsection{The operation mode of mortgage securitization in America}

America is the birthplace of mortgage securitization, is also one of the largest market, in which the US government has played an invaluable role ${ }^{[6]}$.

\subsection{The institutions established of mortgage securitization}

It establishes the Federal Housing Administration Commission, which provides insurance support. It establishes the Federal National Mortgage Association. It establishes the Government National Mortgage Association to improve efficiency. It establishes Federal Home Loan Mortgage 
Corporation that specially does mortgage securitization.

\subsection{The system support of mortgage securitization}

The US government establishes a unified system for mortgage loans through the FHA, GNMA and other government-sponsored agencies, it forms the standardized contracts. The government provides the policy support of tax, law and transaction and so on.

\subsection{The issue size of mortgage securitization}

Since the late of 1990 s, the scale of subprime mortgages is expanding, the proportion of subprime mortgage loans from $8.7 \%$ in 2002 increase to $20.2 \%$ in 2007, as shown in Table 1.

Table 1 The related data of mortgage in America.

\begin{tabular}{|c|c|c|c|c|}
\hline Year & $\begin{array}{c}\text { All } \\
\text { mortgage } \\
\text { (billion) }\end{array}$ & $\begin{array}{c}\text { Subprime } \\
\text { mortgage } \\
\text { (billion) }\end{array}$ & $\begin{array}{c}\text { The proportion } \\
\text { of subprime } \\
\text { mortgage } \\
\text { account for all } \\
\text { mortgage (\%) }\end{array}$ & $\begin{array}{c}\text { Securitization } \\
\text { of subprime } \\
\text { (billion) }\end{array}$ \\
\hline 2001 & 2215 & 190 & 8.6 & 95 \\
\hline 2002 & 2885 & 231 & 8.0 & 121 \\
\hline 2003 & 3945 & 335 & 8.5 & 202 \\
\hline 2004 & 2920 & 540 & 18.5 & 401 \\
\hline 2005 & 3120 & 625 & 20 & 507 \\
\hline 2006 & 2980 & 600 & 20.1 & 483 \\
\hline
\end{tabular}

The source: The 2007 Mortgage Market Statistical Annual

\subsection{The operation mode of mortgage securitization in Canada[7]}

In 1986, CMHC implemented the residential mortgage securitization, the macro-control of government promotes the secondary housing market to be perfection. The housing finance has a smooth development under the Canadian government's macro-control and guidance. CMHC regulates and manages the mortgage finance market in the whole country, it is becoming the key factors for successful development of the Canadian residential mortgage finance.

\subsection{The operation mode of mortgage securitization in Europe[8]}

The mortgage securitization market in European mostly is the financial institutions that issue the mortgage-backed securitization based on the selfsustaining housing loans. Under the premise of no government credit guarantees, it depends on the enhancement of credit mechanisms to improve credit rating. The securities have low yields and a higher risk rate, it is difficult to win the favor of investors, so its development lags far behind the North America.

\subsection{The operation mode of mortgage securitization in Asia}

The housing development and housing finance system are built up in Japan which are to adapt to the background of post-war economic shortages, lack of housing and the national income level is low. Because of the restrictive of policies and lows, the mortgage securitization in Japan is slowly development.

\subsection{Comparison conclusion}

By examining the above typical mortgage securitization in abroad, we can draw the following conclusions.

First, the government has played a major role in the operation of the mortgage securitization[9]. In the development process of mortgage securitization, the American government has played an important role, the British government has played a major role, the Canada government has played a significant role.

Second, the development of the secondary mortgage market and the primary market is complementary and indispensable. In order to spread the risk, the development of the secondary market has come into being. The operation of the secondary market is inseparable from a rigorous transaction structure, investors have a high quality demanding on the mortgage asset in the primary market. The primary mortgage market is the driving force for the development of the secondary market.

\section{THE MODEL CLASSIFICATION AND COMPARISON OF MORTGAGE SECURITIZATION IN DIFFERENT COUNTRIES AND REGIONS}

Through the depth analysis of the operation mode of mortgage securitization in developed countries and regions, the above countries and regions involved are summarized as the following structure, as shown in Figure 1.

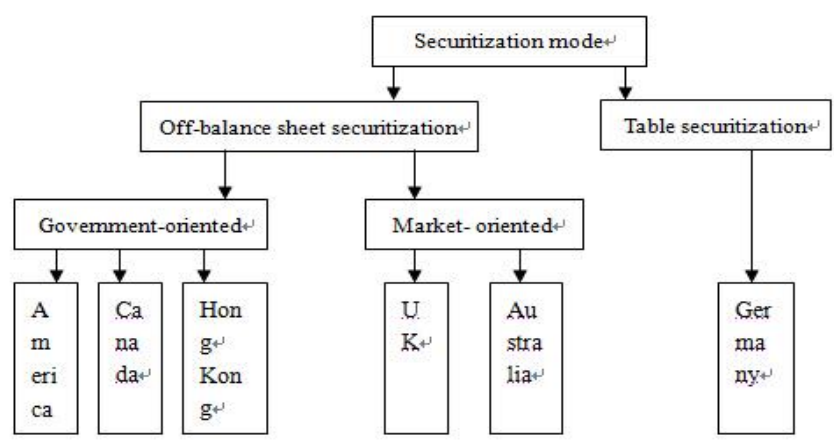


Figure 1 The classification of various mortgage securitization model

Looking at the operation mode of mortgage securitization among the countries, they can be broadly divided into the following three categories[10].

First, government-oriented mode. The feature of this model is that the government has established institutions, they play a leading role in securitization, the US as the representative. The mortgage-backed securitization as the most important financial innovations of the 20th century is coming from the United States.

Second, simi-government semi-market mode. CMHC purchases mortgage or does securitized business according to their asset position. In addition, CMHC also offers a number of specialized programs to help low-income persons. CMHC has an important government functions, but its mainly through market-oriented operation.

Third, market-oriented mode. We choose Australia for example, the mortgage securitization in this country is entirely a commercial model, it need the companies that are founded by commercial banks or investment banks to operate. The central bank of Australia has a regulation, MBS issued by commercial banks must be outside the operating table, through the establishment of SPV holding mortgage assets and the issuance of bonds, this is to ensure the commercial banks away from mortgage debt risk and protect the interests of depositors.

\section{CONCLUSION}

By examining the above typical foreign mortgage securitization model, we can draw the following conclusions.

\subsection{The government has played a major role in the operation of the mortgage securitization}

In the development process of mortgage securitization, the American government has played an important role, the British government has played a major role, the Canada government has played a significant role.

\subsection{The development of the secondary mortgage market and the primary market is complementary and indispensable}

In order to spread the risk, the development of the secondary market has come into being. The operation of the secondary market is inseparable from a rigorous transaction structure, investors have a high quality demanding on the mortgage asset in the primary market. The primary mortgage market is the driving force for the development of the secondary market.

\section{ACKNOWLEDGEMENTS}

This paper is from "The preferred project funded plan of enterprise post doctoral innovation project in Tianjin"

\section{REFERENCES}

[1] Black F, Derman E, Toy W. A one factor model of interest rates and its application to treasury bond options. Financial Analysts Journal, 1990, 46(1): 33-39.

[2] Heath D, Jarrow R, Morton A. Bond pricing and the term structure of interest rates: A new methodology for contingent claims valuation. Econometrica, 1992, 60(1): 77-105.

[3] Hull J, White A. One-Factor interest rate models and the valuation of interest rate derivative securities. Journal of Financial and Quantitative Analysis, 1993, 28(2): 235253.

[4] Chen Zhao. Mortgage theory and practice. Shanghai: Fudan University Press, 2000.

[5] Australia, Hong Kong. The report of mortgage securitization. Mortgage Securitization Mission, 2001.

[6] The United States, Canada. The report of mortgage securitization investigation. Chinese delegation housing finance system, 2002.

[7] Zhang Qiaoyun, Wu Jing. The US mortgage market risk transfer and diffusion amplification and reflux mechanisms. Economists, 2009(2):76-85.

[8] Wang Min. The international regulatory reform and future development of asset securitization market. Southwest Finance, 2011(3):26.

[9] Black F, Karasinski P. Bond and option pricing when short rates are lognormal. Financial Analysts Journal, 1991, 47(4): 52-59.

[10] Chen Hui. The optimal estimation and application of the term structure research. Changsha: College of Business Administration of Hunan University, 2006: 43-44. 